\title{
Deafness and Permanently Reduced Potassium Channel Gene Expression and Function in Hypothyroid Pit ${ }^{\mathrm{dw}}$ Mutants
}

\author{
Mirna Mustapha, ${ }^{1}$ Qing Fang, ${ }^{1}$ Tzy-Wen Gong, ${ }^{2}$ David F. Dolan, ${ }^{2}$ Yehoash Raphael, ${ }^{2}$ Sally A. Camper, ${ }^{1}$ and \\ R. Keith Duncan ${ }^{2}$ \\ Departments of ${ }^{1}$ Human Genetics and ${ }^{2}$ Otolaryngology, University of Michigan Medical School, Ann Arbor, Michigan 48109-5618
}

\begin{abstract}
The absence of thyroid hormone (TH) during late gestation and early infancy can cause irreparable deafness in both humans and rodents. A variety of rodent models have been used in an effort to identify the underlying molecular mechanism. Here, we characterize a mouse model of secondary hypothyroidism, pituitary transcription factor $1\left(P i t 1^{\mathrm{dw}}\right)$, which has profound, congenital deafness that is rescued by oral TH replacement. These mutants have tectorial membrane abnormalities, including a prominent Hensen's stripe, elevated $\beta$-tectorin composition, and disrupted striated-sheet matrix. They lack distortion product otoacoustic emissions and cochlear microphonic responses, and exhibit reduced endocochlear potentials, suggesting defects in outer hair cell function and potassium recycling. Auditory system and hair cell physiology, histology, and anatomy studies reveal novel defects of hormone deficiency related to deafness: (1) permanently impaired expression of KCNJ10 in the stria vascularis of Pit ${ }^{\mathrm{dw}}$ mice, which likely contributes to the reduced endocochlear potential, (2) significant outer hair cell loss in the mutants, which may result from cellular stress induced by the lower KCNQ4 expression and current levels in Pit ${ }^{\mathrm{dw}}$ mutant outer hair cells, and (3) sensory and strial cell deterioration, which may have implications for thyroid hormone dysregulation in age-related hearing impairment. In summary, we suggest that these defects in outer hair cell and strial cell function are important contributors to the hearing impairment in $P i t 1^{\mathrm{dw}}$ mice.
\end{abstract}

Key words: secondary hypothyroidism; tectorial membrane; KCNQ1; KCNQ4; KCNJ10; prestin; POU1F1

\section{Introduction}

The organ of Corti is a neuroepithelium with sensory cells known as inner (IHC) and outer hair cells (OHCs). Its maturation in the early postnatal period in mice and during the late prenatal period in humans is highly sensitive to thyroid hormone (TH), as $\mathrm{TH}$ deficiency during these periods can cause irreparable hearing deficits (Deol, 1973; Van't Hoff and Stuart, 1979; Uziel et al., 1983, 1986; Vanderschueren-Lodeweyckx et al., 1983). TH activates and represses expression of many genes by interacting with $\mathrm{TH}$ receptors (THR). Some TH regulated genes encode functionally

\footnotetext{
Received 0ct. 14, 2008; revised Dec. 12, 2008; accepted Dec. 19, 2008.

This work was supported in part by the Deafness Research Foundation (M.M.), March of Dimes Grant 6-FY08-262 (S.A.C.), National Institutes of Health Grants DC05053 (S.A.C.), P30 DC05188 (D.F.D.), and DC05401 (Y.R.), the Margaret G. Bertsch Research Endowment (Margaret I. Lomax), and the University of Michigan Office of the Vice President for Research, Biomedical Research Council, and a Clinical and Translational Science Award (S.A.C.). The immunohistochemical analyses by whole mount and sectioning, and animal colony maintenance were done by M.M. and Q.F. DPOAE, CM, and EP were done by D.F.D. T.-W.G. contributed to the study of OHC loss. Y.R. analyzed the TEM. Nonlinear capacitance and KCNQ4 current measurements were done by R.K.D. Conceptualization of the experimental design and preparation of this manuscript was done by M.M., S.A.C., and R.K.D. We thank the following individuals for their important contributions to this work: Margaret I. Lomax for intellectual contributions and financial support, Alicia Giordimaina and Albert Chow for statistical analysis, Lisa A. Beyer for TEM and scanning electron microscopy, Karin Halsey and Jennifer Benson for physiological tests (DPOAE, CM and EP), Dr. Hassan Chaib for Western blot analysis, Dr. Guy Richardson for the $\beta$-tectorin antibody, and Dr. Jentsch for the KCNQ4 antibody.

Correspondence should be addressed to Sally A. Camper, Department of Human Genetics, University of Michigan Medical School, 4909 Buhl Building, 1241 Catherine Street, Ann Arbor, MI 48109-5618. E-mail: scamper@umich.edu.

DOI:10.1523/JNEUROSCI.4957-08.2009

Copyright $\odot 2009$ Society for Neuroscience $\quad 0270-6474 / 09 / 291212-12 \$ 15.00 / 0$
}

important proteins that are involved in structural development and/or physiological processes of the inner ear. Although several candidate genes have been proposed based on studies with rodent models of hypothyroidism, the molecular basis for the permanent nature of hypothyroidism-induced hearing loss is still unclear (Uziel, 1986; Knipper et al., 1998, 2000; Rusch et al., 1998; Zheng et al., 2000; Abe et al., 2003; Cantos et al., 2003; Rueda et al., 2003; Winter et al., 2006; Brandt et al., 2007; Sendin et al., 2007).

To explore the mechanism whereby TH affects the development and function of the inner ear, we characterized Snell dwarf (Pit $1^{\mathrm{dw}}$, officially Poulf1 ${ }^{\mathrm{dw}}$ ), a mouse model of secondary hypothyroidism. These mice have an inactivating missense mutation in the Pit1 gene, which encodes a POU-homeodomain transcription factor that is highly expressed in the pituitary gland (Camper et al., 1990; Li et al., 1990). The gene is necessary for development of the cells that produce growth hormone $(\mathrm{GH})$, prolactin (PRL), and thyroid-stimulating hormone (TSH) (Gage et al., 1996). If untreated, homozygous mutants exhibit growth insufficiency, infertility, hypothyroidism, and deafness. Auditory brainstem response (ABR) testing revealed profound deafness in Pit ${ }^{\mathrm{dw}}$ mutants at both 3 and 6 weeks of age, but continuous oral thyroid hormone supplementation initiated late in gestation was effective in preventing hearing deficits (Karolyi et al., 2007). Because TH replacement does not rescue the deficiency in GH or PRL, the deafness is attributable to hypothyroidism. In addition, there are 
no reports of hearing deficits caused by GH or PRL deficiency, and GH deficient little mutants (Ghrhr ${ }^{\text {lit }}$ ) have normal ABR thresholds (OMIM, K. R. Johnson, personal communication) (Godfrey et al., 1993; Lin et al., 1993). The Pit ${ }^{\mathrm{dw}}$ mutant mice are viable and healthy, living $\sim 40 \%$ longer than their normal littermates (Brown-Borg et al., 1996). We selected these mutants for further characterization because of their viability, profound deafness, simple, autosomal recessive inheritance of hypothyroidism, and responsiveness to TH supplementation (Karolyi et al., 2007).

We report physiological, morphological, and gene expression analyses over the course of cochlear development in normal and Pit ${ }^{\mathrm{dw}}$ mutant mice. Tectorial membrane (TM) composition, morphology, and ultrastructure are altered. OHC function is permanently compromised, as demonstrated by the absence of distortion product oto-acoustic emissions (DPOAE) and cochlear microphonics (CM). In addition to defects in $\mathrm{OHC}$ function, Pit ${ }^{\mathrm{dw}}$ mice have reduced endocochlear potential (EP). We examined expression of prestin and KCNQ4 in OHCs, as well as KCNQ1 and KCNJ10 in the stria vascularis, as candidates for underlying mechanisms. We identified some processes that are developmentally delayed but eventually mature in hormonedeficient mice and others that suffer lasting deficits, likely contributing to the permanent hearing problems caused by hypothyroidism. This study advances our understanding of the role that hormones play in development of normal hearing, including permanent effects on the tectorial membrane, expression of the potassium channel genes KCNQ4 and KCNJ10, the survival of $\mathrm{OHCs}$, and deterioration of the intermediate cells in the stria vascularis.

\section{Materials and Methods}

Animal care and genotyping. All experiments were approved by the University Committee on the Use and Care of Animals and conducted in accord with the principles and procedures outlined in the National Institutes of Health Guidelines for the Care and Use of Experimental Animals. Mice were obtained from The Jackson Laboratory in 1990 and maintained at the University of Michigan. Previously described procedures for animal care and genotyping were used, including feeding mice a higher fat chow designed for breeding (PMI5020), delaying weaning of mutants until $\sim 35 \mathrm{~d}$, and housing mutants with normal littermates to provide warmth (Karolyi et al., 2007). In all experiments, at least 3 animals of each genotype were analyzed for each age group studied unless stated otherwise. Postnatal day zero (P0) is designated as the day of birth.

Histology and gene expression analysis. Western blot analysis was performed with organ of Corti protein extracts collected from postnatal animals. Protein samples were homogenized in T-PER buffer (Pierce, Thermo Fisher Scientific), denatured in Laemmli sample buffer, and loaded onto SDS-polyacrylamids gels (12\%). Gels were blotted onto nitrocellulose filters, and filters were probed with rabbit anti- $\beta$ tectorin antibody (gift from Dr. Richardson, University of Sussex, UK) at 1:1000 dilution. As a loading control, blots were subsequently probed with antiglyceraldehyde-3-phosphate dehydrogenase (GAPDH) antibody (Santa Cruz Biotechnology s.c.-25778) at the dilution of 1:2000 and developed with an HRP-conjugated goat anti-rabbit (Pierce Biotechnology cat\# 31462). Blots were developed with ECL substrate (Santa Cruz Biotechnology s.c.-2048).

Animals aged $\mathrm{P} 8$ and older were killed by $\mathrm{CO}_{2}$ inhalation or decapitation. The temporal bones were avulsed and cochleae were quickly transferred into $4 \%$ paraformaldehyde in $0.1 \mathrm{~m}$ PBS, $\mathrm{pH}$ 7.4. The footplate of the stapes was removed and each cochlea was perfused with the fixative introduced through the oval and round windows and extruded through a small opening made at the apex. The tissues were exposed to the fixative for $2 \mathrm{~h}$, followed by overnight incubation (with shaking) at $4^{\circ} \mathrm{C}$ in $8 \%$ EDTA for decalcification. No decalcification was applied to ears from animals younger than $\mathrm{P} 10$.
Fixed tissues were prepared for sectioning by embedding in paraffin or OCT. Soft bone specimens were dehydrated through a graded ethanol series and embedded in paraffin wax, sectioned at $6 \mu \mathrm{m}$ thickness, mounted, dried for $2 \mathrm{~h}$, and stored at room temperature. Alternatively, soft bone specimens were incubated in $30 \%$ sucrose overnight at $4^{\circ} \mathrm{C}$, embedded in OCT, cryosectioned at $6 \mu \mathrm{M}$ thickness, mounted, dried for $15 \mathrm{~min}$, and stored at $-20^{\circ} \mathrm{C}$.

Cochlear cryosections were blocked with $5 \%$ goat or donkey serum and $0.1 \%$ Triton X-100 in $0.1 \mathrm{M}$ PBS for $1 \mathrm{~h}$ at room temperature, and incubated overnight at $4^{\circ} \mathrm{C}$ with a rabbit antiserum against $\mathrm{KCNJ} 10$ (1: 300 , Alomone), or a rabbit polyclonal antibody against KCNQ4 (1:300) (Kharkovets et al., 2006), which was kindly provided by T. Jentsch (Hamburg University, Germany). Cochlear paraffin sections were dewaxed, rehydrated and boiled in $10 \mathrm{~mm}$ citric acid, $\mathrm{pH}$ 6, for $10 \mathrm{~min}$ to unmask epitopes followed by $1: 1 \mathrm{H}_{2} \mathrm{O}_{2}$ :methanol (v/v) for $20 \mathrm{~min}$ to quench the endogenous peroxidase activity. The sections were incubated overnight at $4^{\circ} \mathrm{C}$ with a goat polyclonal antibody against prestin $(\mathrm{N}-20)(1: 200$, Santa Cruz) and mouse monoclonal antibody against synaptophysin (1: 400, Sigma). Immunolabeling was visualized with TRITC-labeled secondary antibody (1:200, Jackson Immunoresearch) or Alexa Fluor 488 conjugated secondary antibodies (1:200, Invitrogen) and counterstained with DAPI (Vector Laboratories). Sections from wild-type and mutant animals were processed in parallel for histology and immunostaining. Tissues were analyzed and photographed on a Leica DMRB epifluorescence microscope using identical light and exposures for mutant and wild-type littermates.

For transmission electron microscopy analysis, animals were anesthetized and fixed by intracardiac perfusion with $2.5 \%$ glutaraldehyde in $0.15 \mathrm{~m}$ cacodylate buffer, $\mathrm{pH} 7.2$, containing $1 \%$ tannic acid. The inner ear was removed and immersed into the same fixative for $2 \mathrm{~h}$. The tissues were decalcified for 1 week in 3\% EDTA with $0.25 \%$ glutaraldehyde at $4^{\circ} \mathrm{C}$. The inner ears were postfixed with $1 \%$ osmium tetroxide in phosphate buffer for $1 \mathrm{~h}$. The specimens were dehydrated in increasing ethanol concentrations and embedded in Embed 812 epoxy resin. Sections were taken on a Leica Ultracut $\mathrm{R}$ using a diamond knife, stained with uranyl acetate and lead citrate, and examined on a Philips CM-100 TEM (Beyer et al., 2000; Russell et al., 2007).

Scanning electron microscopy, whole mount and phalloidin epifluorescence analyses were performed as previously described (Beyer et al., 2000; Mustapha et al., 2007).

Standard tests of auditory physiology. DPOAEs and EP were conducted as previously described (Karolyi et al., 2007).

$\mathrm{CM}$ measurements were performed on mice that were anesthetized (ketamine $65 \mathrm{mg} / \mathrm{kg}$, xylazine $3.5 \mathrm{mg} / \mathrm{kg}$, and acepromazine $2 \mathrm{mg} / \mathrm{kg}$ ) and given a dose of glycopyrrolate $(0.2 \mathrm{mg} / \mathrm{kg})$ to reduce secretions during surgery. Body temperature was maintained through the use of water circulating heating pads and heat lamps. Additional anesthetic (ketamine and xylazine) was administered if needed to maintain anesthesia at a depth sufficient to insure immobilization and relaxation. Mice were placed into a head holder. The external pinna was removed and soft tissue dissected away from the bulla. The bulla wall was opened, and a single ball electrode, $\sim 100$ micrometer in diameter, was placed in the round window niche. The electrode was made from 2 T $90 \%$ platinum $/ 10 \%$ iridium wire and Teflon coated, except for the ball. A Teflon-coated silver return electrode was placed subcutaneously on the jawline. For CM recordings, the output frequency from the SRS 830 lock-in amplifier was stepped from 4 to $30 \mathrm{kHz}$, with a time constant of one second and a dwell time of 300 microseconds. The signal was passed through a programmable attenuator (TDT PA5) to produce a constant-amplitude signal. The signal from the round window electrode (Teflon-coated silver wire, with reference in the contralateral jawline) was sent through a Grass P15 amplifier (filter 0.1-50 $\mathrm{kHz}$ ) to the input of the SRS830 lock-in amplifier. Signals were generated and data recorded with a MATLAB script written in-house.

Patch-clamp electrophysiology. Preparations of semi-intact mouse organ of Corti were obtained from mice 2 to 6 weeks old. Mice were anesthetized by intraperitoneal injection of ketamine $(65 \mathrm{mg} / \mathrm{kg})$ and xylazine $(7 \mathrm{mg} / \mathrm{kg}$ ) and killed by rapid decapitation. The bony labyrinth was extracted into cold perilymph-like saline (in $\mathrm{mm}, 142.0 \mathrm{NaCl}, 5.8 \mathrm{KCl}, 1.3$ $\mathrm{CaCl}_{2}, 0.9 \mathrm{MgCl}_{2}, 10 \mathrm{HEPES}, 0.7 \mathrm{Na}_{2} \mathrm{HPO}_{4}, 2 \mathrm{Na}$-pyruvate, 5.8 glucose; 
pH 7.4; $305 \mathrm{mOsm}$ ), supplemented with amino acids and vitamins (1X MEM, Invitrogen). Approximately three-quarters of the apical cochlear coil was separated from the modiolus and spiral ligament. All recordings were from OHC located approximately one-half turn from the cochlear apex. Viable hair cells were identified by their appearance, including features of birefringent membrane, columnar shape and absence of observable Brownian motion in cell organelles. Whole-cell voltage-clamp recordings were made with a MultiClamp 700B and Digidata 1440A data acquisition system using the pClamp 10.0 software suite (Molecular Devices). Data were sampled at $20 \mathrm{kHz}$ and low-pass filtered at $4 \mathrm{kHz}$. For measurements of nonlinear capacitance, electronic compensation of membrane capacitance was necessarily omitted. Data were obtained from all three rows of OHC. Currents were recorded several minutes after break-in to the whole-cell configuration, to allow the cytoplasm and pipette solution to equilibrate. Electrodes were pulled from borosilicate glass capillaries (World Precision Instruments) to a resistance of 3-6 $\mathrm{M} \Omega$. Drug perfusions, when necessary, were delivered locally through a multichannel micromanifold (ALA Scientific). All recordings were made at room temperature $\left(21-26^{\circ} \mathrm{C}\right)$. Membrane voltages have not been compensated for junction potentials or residual series resistance errors. Unless otherwise noted, all measurements are reported as means \pm 1 SEM.

Voltage-dependent capacitance was estimated from current transients elicited by small, incremental steps in the command voltage. This method, described more fully elsewhere (Huang and Santos-Sacchi, 1993; Oliver and Fakler, 1999), relies on a simplified electrical model of the cell, under conditions where ionic currents have been blocked. The voltage protocol consisted of a stair-step series of voltage commands from -125 to $70 \mathrm{mV}$, using brief $5 \mathrm{mV}$ steps $10 \mathrm{~ms}$ in duration. Extracellular and intracellular solutions were designed to block dominant potassium and calcium currents, resulting in a nearly linear steady-state current-voltage curve. The extracellular solution consisted of the following (in mM): $100 \mathrm{NaCl}, 20 \mathrm{CsCl}, 20$ TEA-Cl, $1.52 \mathrm{MgCl}_{2}, 2 \mathrm{CoCl} 2,10$ HEPES, 5 glucose, with $\mathrm{pH}$ adjusted to 7.2 using $\mathrm{NaOH}$ and osmolarity set to $\sim 300 \mathrm{mOsm}$. The intracellular solution contained the following (in mM): $140 \mathrm{CsCl}, 2 \mathrm{MgCl} 2,10 \mathrm{HEPES}, 10 \mathrm{EGTA}$, with $\mathrm{pH}$ adjusted to 7.2 using $\mathrm{CsOH}$ and osmolarity set to $\sim 300 \mathrm{mOsm}$.

Membrane capacitance was calculated from estimates of input resistance and monoexponential fits to capacitance transients. These calculations were plotted against the voltage command eliciting the transient and fit to the derivative of the Boltzman equation describing charge movement through the membrane electric field:

$$
C_{\mathrm{m}}(V)=C_{\operatorname{lin}}+\frac{Q_{\max }}{\alpha e^{\left(\left(V_{\mathrm{m}}-V_{1 / 2}\right) / \alpha\right)}\left(1+e^{\left(\left(V_{\mathrm{m}}-V_{1 / 2}\right) /-\alpha\right)}\right)^{2}},
$$

where $V_{\mathrm{m}}$ is membrane voltage, $C_{\operatorname{lin}}$ is the linear, voltage-independent membrane capacitance, $Q_{\max }$ is the maximum charge moved through the membrane electric field, $V_{1 / 2}$ is the voltage corresponding to halfmaximum charge movement, and $\alpha$ is the Boltzman slope factor describing voltage-sensitivity. The maximum voltage-dependent capacitance $\left(C_{\text {nonlin }}\right)$ is equal to $C_{\mathrm{m}}\left(V_{1 / 2}\right)-C_{\text {lin }}$.

For potassium current measurements, the bath solution was the perilymph-like saline used for dissection (see above), and the electrode solution contained (in mM): $135 \mathrm{NaCl}, 0.1 \mathrm{CaCl}_{2}, 3.5 \mathrm{MgCl}_{2}, 5 \mathrm{HEPES}, 5$ EGTA, and $2.5 \mathrm{Na}_{2} \mathrm{ATP}$, with $\mathrm{pH}$ adjusted to 7.2 with $\mathrm{KOH}$ and osmolarity set to $292 \mathrm{mOsm}$. Voltage commands were referenced to a holding potential of $-80 \mathrm{mV}$ in all cases. Tail currents were corrected off-line for a linear leak conductance and fit with a first-order Boltzman function:

$$
I\left(V_{\mathrm{m}}\right)=\frac{I_{\max }}{1+e^{-\left(V_{\mathrm{m}}-V_{1 / 2}\right) / V_{\mathrm{s}}}}
$$

where $I_{\max }$ is the maximum tail current, $V_{\mathrm{m}}$ is the membrane voltage, $V_{1 / 2}$ is the half-maximal activation voltage, and $V_{\mathrm{s}}$ is the Boltzman slope factor describing voltage sensitivity. In many cases, the sum of two firstorder Boltzman functions was required to describe the tail currents. The F-statistic from curve fits in pClamp was used to determine whether a single or double Boltzman equation best fit the data. In some cases, the
M-current blocker linopirdine $(200 \mu \mathrm{M})$ was locally applied to selectively block KCNQ4 currents (Marcotti and Kros, 1999).

\section{Results}

\section{Altered composition of the tectorial membrane in Pit1 ${ }^{\mathrm{dw}}$ mutant mice}

The morphological maturation of the cochlea is subject to developmental delay in mice with disrupted TH receptors, Thra, Thrb, which are unable to respond to TH. Similar features of developmental delay are noted in many types of hypothyroid mice, including pituitary TSH deficient Cga mutants and pharmacologically induced hypothyroidism (Deol, 1973; Uziel et al., 1983, 1986; Li et al., 1999; Rusch et al., 2001; Karolyi et al., 2007). We compared mid-modiolar cochlear sections of Pit $1^{\mathrm{dw}}$ mutants and wild-type littermates using light microscopy. We observed a delay in the opening of the tunnel of Corti in Pit ${ }^{\mathrm{dw}}$ mutants at P12, but by $\mathrm{P} 21$ the opening was indistinguishable from wild type (Fig. $1 A)$. These features are similar to those described in other hypothyroid mutants. At P21 the tectorial membrane (TM) in Pit1 ${ }^{\mathrm{dw}}$ mutants clearly contains an abnormal protrusion (Fig. $1 A$ ). This abnormality appears to be a more prominent Hensen's stripe, and it persists through P42 (data not shown). This prominent stripe is evident in another model of secondary hypothyroidism, the Cga mutant that lacks pituitary TSH, but neither the underlying mechanism nor the significance has been explored (Karolyi et al. 2007).

The tectorial membrane is comprised of collagens (Col11a2, Col9a3, and Col9a1) and noncollagen proteins including $\alpha$-tectorin (Tecta) and $\beta$-tectorin (Tectb) and otogelin (Otog), all of which are critical for normal hearing (Richardson et al., 2008). We compared the concentration of TECTB in cochlear protein extracts from normal and Pit $1^{\mathrm{dw}}$ mutant mice at P21 using Western blotting (Fig. $1 \mathrm{~B}$ ). Two expected TECTB polypeptides are detected in all mutant and wild-type samples, consistent with previous reports (Knipper et al., 2001). Both isoforms of TECTB are consistently elevated in the Pit $1{ }^{\mathrm{dw}}$ mutant samples compared with wild-type littermates. Similar results were obtained at P35 (data not shown). The elevation of TECTB in Pit ${ }^{\mathrm{dw}}$ mutants contrasts with the significant reduction of TECTB in druginduced hypothyroid rats (Knipper et al., 2001).

Structural changes in the TM have been reported in a variety of models with altered TH (Knipper et al., 2001; Rusch et al., 2001; Richardson et al., 2008). Transmission electron microscopy (TEM) revealed abnormalities in the structure of the striatedsheet matrix in the TM in Pit ${ }^{\mathrm{dw}}$ mutants relative to wild type (Fig. 1C).

\section{OHC loss in Pit1 ${ }^{\mathrm{dw}}$ mutant mice}

To examine maturation of cochlear sensory cells and supporting cells we prepared whole mounts of the organ of Corti from normal and mutant mice and stained them with FITC-phalloidin, which reveals actin-containing regions of the cytoskeleton and cell-cell contacts (Fig. 2A-D). At P14 and P25 the stereocilia of IHCs and $\mathrm{OHCs}$ and the junctions between pillar cells are clearly visible in wild-type mice (Fig. $2 A, C$ ). In contrast, the pillar cells do not stain with phalloidin in P14 mutants (Fig. 2 B). At P25 the mutant pillar cells stain with phalloidin, but the organization of the cytoskeleton is abnormal relative to normal mice, and these abnormalities persist through P42 (data not shown). Disruptions are evident in the repeated pattern of OHCs and the orientation of the OHC hair bundles in both P14 and P25 Pit ${ }^{\mathrm{dw}}$ mutants compared with wild type, suggesting the possibility of $\mathrm{OHC}$ death, followed by scar formation in the mutants (Fig. $2 B, D$ ). 
A
Wild type
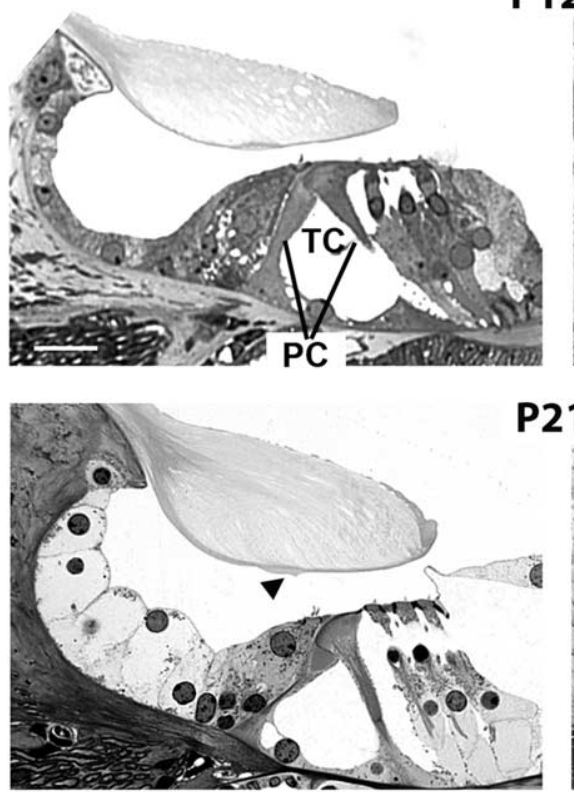

Pit $1^{\text {dw }}$

P12

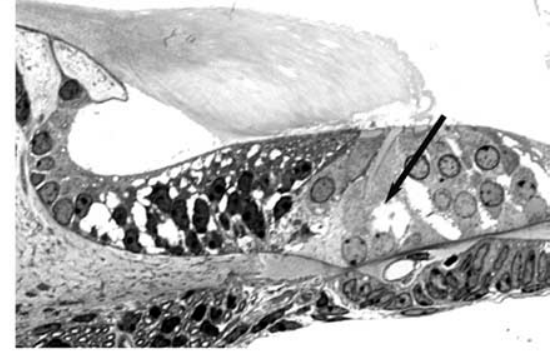

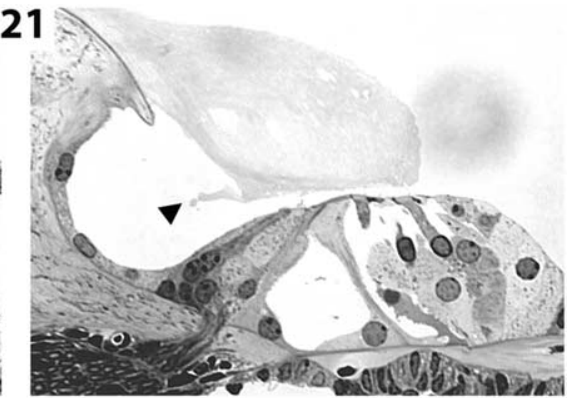

B

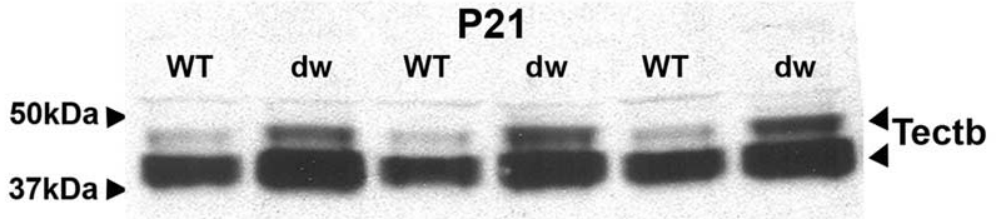

C
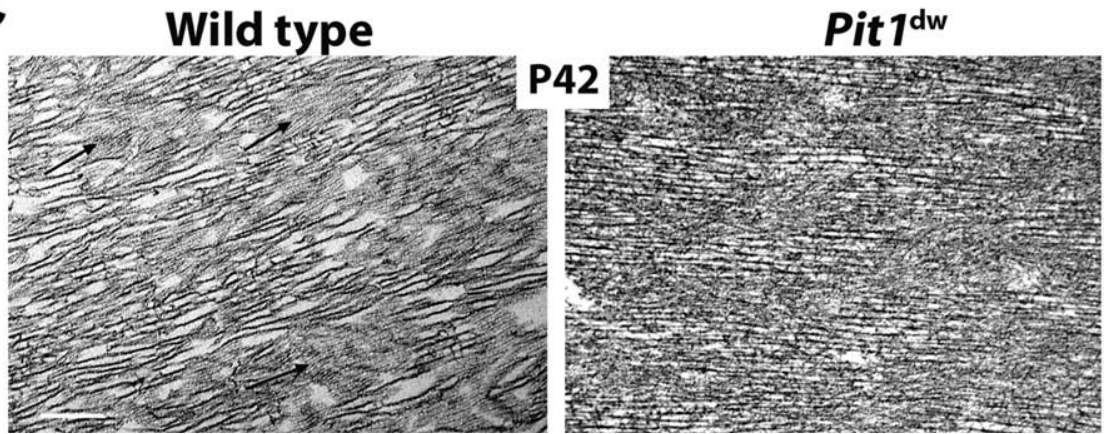

Figure 1. Tectorial membrane abnormalities in Pit ${ }^{\mathrm{dw}}$ mice. $\boldsymbol{A}$, Plastic sections of the organ of Corti taken from wild-type and Pit ${ }^{\mathrm{dw}}$ mutant mice at P12 and P21 were visualized by light microscopy. The arrow indicates the unopened tunnel of Corti (TC) in the P12 old mutant. OHCS, IHCs, and pillar cells (PC) are indicated. Scale bars: $10 \mu \mathrm{m}$. $\boldsymbol{B}$, Analysis of TECTB content in the tectorial membrane of P21 animals using Western blotting. Two polypeptide bands of TECTB are present at $\sim 43$ and $47 \mathrm{kDa}$. The blot was reprobed with a GAPDH antibody, and equivalent amounts of immunoreactive $\sim 36 \mathrm{kDa}$ protein were detected, indicating equivalent amounts of proteins were loaded (data not shown). C, Transmission electron micrographs illustrate the ultrastructure of the tectorial membrane in P42 old animals. Regions shown are from the central core of the tectorial membrane overlying the organ of Corti. Fine diameter filaments (arrows) forming the striated sheet matrix are different in the wild-type mice and the mutants. Scale bars: $2 \mu \mathrm{m}$.

We performed two additional types of analyses on P42 mutant and wild-type mice to examine OHC death more closely. Scanning electron microscopy of the organ of Corti clearly confirmed the presence of scars in mutant mice in the cochlear mid turn, indicating the expansion of supporting cells into spaces created by missing OHCs (Fig. 2E,F). TEM analyses revealed $\mathrm{OHCs}$ from the mid turn of P42 Pit ${ }^{\mathrm{dw}}$ mutant in an advanced stage of degeneration (Fig. 2G). To determine the location and extent of $\mathrm{OHC}$ death along the cochlea, we analyzed whole mounts of $\mathrm{P} 42$ organ of Corti by staining OHCs with FITC-phalloidin (data not shown) and antibody to the motor protein prestin (supplemental Figure S. 1A, $B$, available at www.jneurosci.org as supplemental material). Four regions of the organ of Corti were examined and quantified for OHC loss (apex, lower apex, mid turn and upper base) in 5 different animals of both $P i t 1^{\mathrm{dw}}$ mutant and wild-type mice. Two-sided Student's $t$ tests for independent samples were conducted for differences in the mean between mutants and wild-type mice. Gaps and deviations from the normal pattern of three, well organized rows of OHCs were observed throughout the mutant organ of Corti. The most prominent hair cell loss was in the lower apical region of $P i t 1^{\mathrm{dw}}$ mutants with a mean percentage loss of $15 \pm 2 \%$ (mean \pm 1 SEM) compared with wild-type mice at $3 \pm 2 \%$ (Fig. $2 \mathrm{H}$ ). Mean percentage $\mathrm{OHC}$ loss was significantly higher in the Pit $1^{\mathrm{dw}}$ mutants compared with wild type in the lower apex $(p<0.01)$, mid turn $(p<$ $0.01)$, and upper base $(p<0.05)$, but not significantly higher in the apex. A similar gradient of hair cell loss was described for Barhll mutants (Li et al., 2002). OHC degeneration occurs in the $\mathrm{Pax}^{-/-}$model of hypothyroidism, but Pax8 expression in the otocyst could be a confounding factor (Patuzzi et al., 1989; Christ et al., 2004). Because most Pit $1^{\mathrm{dw}}$ OHC survive and have a healthy appearance, the OHC death we observe in Pit ${ }^{\mathrm{dw}}$ mutants is unlikely to account for the profound hearing impairment. The remaining OHCs might be dysfunctional, however.

\section{Adult Pit ${ }^{\mathrm{dw}}$ mice lack DPOAE and CM} OHCs contribute to sound processing by serving as a nonlinear cochlear amplifier. We used standard audiometric techniques to test $\mathrm{OHC}$ function by measuring DPOAEs and CMs because normal morphological appearance does not imply normal OHC function. Wild-type 6-weekold (P42) animals had DPOAEs at low and moderate sound levels ( $\leq 80 \mathrm{~dB}$ SPL) at all frequencies measured $(12,24$, and $48 \mathrm{kHz})$ (shown for $24 \mathrm{kHz}$ ) (Fig. 3A). Postmortem DPOAE measurements on wild-type mice define the noise floor. Live, age-matched Pit ${ }^{\mathrm{dw}}$ mutant littermates had DPOAEs that were indistinguishable from the noise floor in mutant or wild-type mice. We also recorded the magnitude and phase of the cochlear microphonic, a measure of the combined sound-driven receptor currents of both IHCs and OHCs. The CM response is dominated by the more numerous OHCs, particularly those OHCs located at the base of the cochlea close to the recording electrode (Patuzzi et al., 1989). CM amplitude was detected at all sound stimulation frequencies (4 through $30 \mathrm{kHz}$ ) in 6-week old (P42) wild-type animals (Fig. 3B). In Pit ${ }^{\mathrm{dw}}$ age-matched offspring CM amplitudes were indistinguishable from those re- 

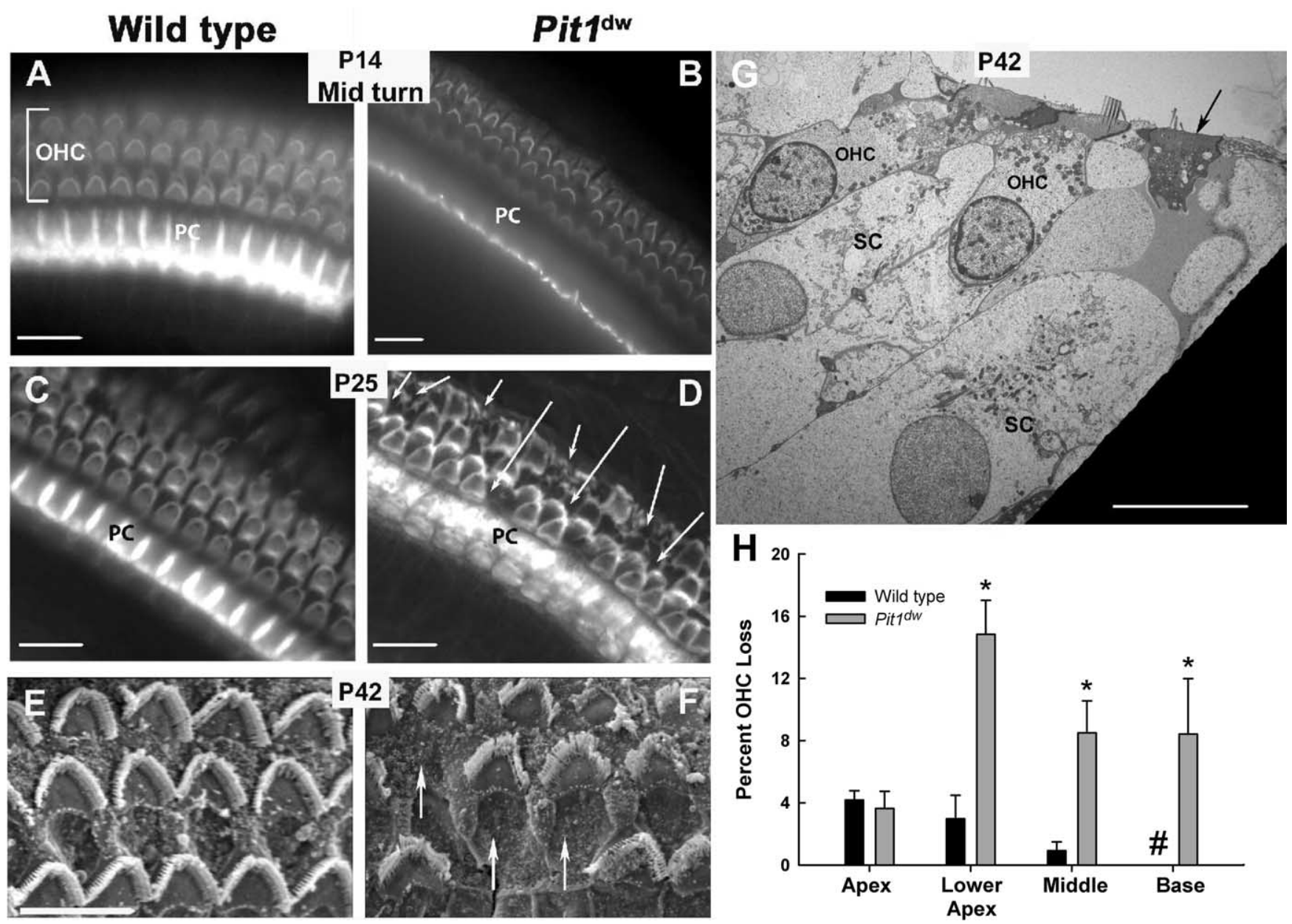

Figure 2. Pit ${ }^{\mathrm{dw}}$ mutants undergo significant $0 \mathrm{HC}$ loss compared with wild-type mice. $\mathbf{A}-\mathbf{D}$, Whole mounts of the organ of Corti of mice ages P14 and P25 were stained with FITC-phalloidin to reveal actin-rich structures and visualized by light microscopy. $\boldsymbol{E}-\boldsymbol{G}$, Scanning electron microscopy $(\boldsymbol{E}, \boldsymbol{F})$ and TEM $(\boldsymbol{G})$ were used to examine the organ of Corti from P42 mice. The TEM reveals that the width of supporting cells (SC) that neighbor degenerating $\mathrm{OHCS}$ (arrow) are larger than $\mathrm{SC}$ neighboring healthy $\mathrm{OHC}$. Pillar cells (PC). Arrows indicate $\mathrm{OHC}$ degeneration and scar formation. Scale bars: $10 \mu \mathrm{m}$. $\boldsymbol{H}$, Outer hair cell loss was quantified by region (apex, lower apex, mid and upper base turns) in five different animals of both Pit ${ }^{\mathrm{dw}}$ mutant and wild-type mice. The length of each region was $100 \mu \mathrm{m}$, encompassing $166-1810 \mathrm{HCs}$ per region. Mean percentage outer hair cell loss was significantly higher in the Pit $1{ }^{\mathrm{dw}}$ mutants compared with the wild-type mice $(*)$ in the lower apex $(p<0.01)$, mid turn $(p<0.01)$, and upper base $(p<0.05)$. No OHC loss was observed in wild-type cochlea at the upper base (\#). All statistical tests were conducted in SPSS 15.0.1.1. Error bars represent one SEM.

corded in postmortem normal animals, indicating compromised $\mathrm{OHC}$ function in the Pit ${ }^{\mathrm{dw}}$ mutants. The lack of a CM response was confirmed by the absence of a frequency-dependent phase shift in the mutants (Fig. 3C). These data suggest that the OHCs in the Pit1 ${ }^{\mathrm{dw}}$ mutants are dysfunctional, despite their normal morphological appearance. Since both CM and DPOAE responses were absent in mutant mice, an OHC specific dysfunction could arise from deficits in the electrical motor response in these cells as well as from aberrant mechanical performance, which could be associated with abnormal properties of the TM.

\section{Maturation of prestin expression and distribution in Pit $^{\mathrm{dw}}$ mice}

Prestin is a member of a distinct family of anion transporters, SLC26, and it is expressed in OHCs but not in the nonmotile IHCs. Prestin, officially known as SLC26A5, is presumably responsible for $\mathrm{OHC}$ electromotility and cochlear amplification (Zheng et al., 2000; Liberman et al., 2002). Prestin mutants exhibit reduced DPOAE, CM and nonlinear capacitance compared with wild type (Liberman et al., 2002; Cheatham et al., 2004; Gao et al., 2007; Dallos et al., 2008). It is not clear, however, whether abnormalities in prestin protein levels, subcellular localization, or function contribute to reduced DPOAEs and CM in Pit ${ }^{\mathrm{dw}}$ mice. To explore these possibilities we performed a developmental time course of immunohistochemical staining for prestin in tissues also stained with DAPI to reveal nuclei and synaptophysin, a presynaptic marker of the efferent synapse at the base of the OHCs. In normal mice, prestin immunoreactivity is evenly distributed throughout the entire $\mathrm{OHC}$ membrane during the first few days after birth (shown for P8) (Fig. 4A). Between P8 and $\mathrm{P} 13$, the subcellular distribution of prestin protein becomes restricted to the lateral regions of the $\mathrm{OHC}$ and is depleted from the basal pole of the OHC membrane (shown for P13) (Fig. 4A). This redistribution in prestin localization begins in the basal turn and propagates toward the apical turn of the cochlea (data not shown).

Pit $1^{\mathrm{dw}}$ mutants exhibit a developmental delay in prestin expression and subcellular localization. Prestin immunoreactivity is qualitatively reduced in $P i t 1^{\mathrm{dw}}$ mutants at $\mathrm{P} 8$ compared with normal littermates (Fig. 4A). The level and localization of prestin expression in Pit ${ }^{\mathrm{dw}}$ mutants are improved at P13, resembling that of wild-type mice at P8. Mutants show continued improvement at P21. By P42 the pattern of prestin expression is indistinguishable from that of 2-week-old wild-type mice. This indicates 


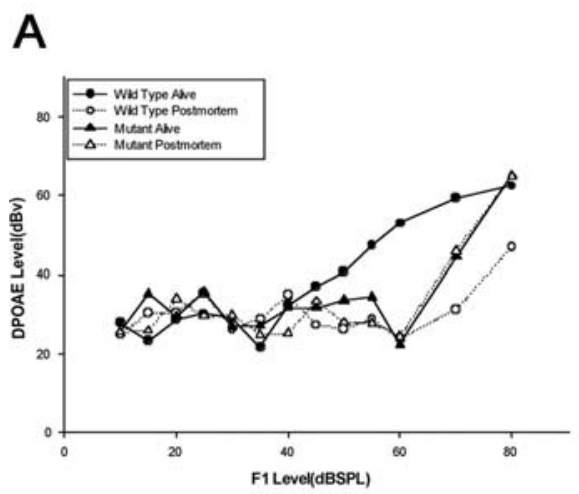

B

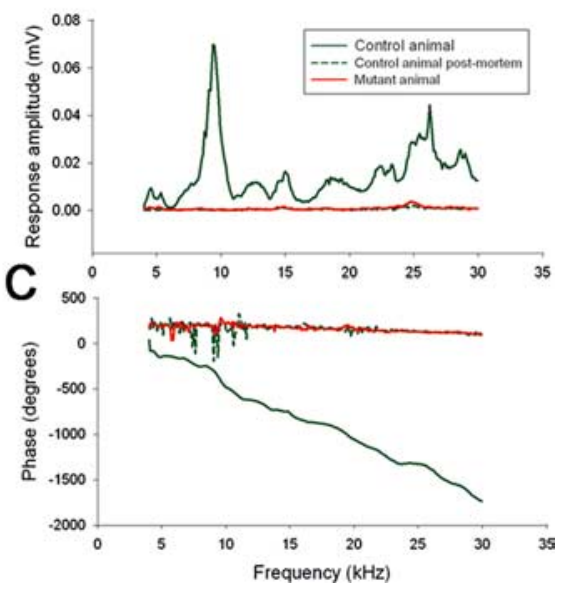

Figure 3. Pit $1^{\mathrm{dw}}$ mutant mice lack DPOAE and CM responses. $\boldsymbol{A}, \mathrm{DPOAEs}$ were measured in alive wild-type and mutant mice at P42 (black circles and black triangles, respectively) and compared with DPOAEs of postmortem animals (white circles and triangles). Data are shown for the $24 \mathrm{kHz}$ frequency only. Error bars indicate \pm 1 SEM. B, C, CM potentials were tested at various sound stimulation frequencies (4 through $30 \mathrm{kHz}$ ) in P42 wild-type animals (green line), in Pit $1^{\mathrm{dw}}$ mutant mice (red line) and in postmortem animals (green dashed line) of age-matched offspring (B).CM amplitudes were confirmed by the phase shift data (C).

a developmental delay of 3 to 4 weeks for maturation of prestin expression and localization in Pit ${ }^{\mathrm{dw}}$ mice.

\section{Maturation of prestin function in Pit $^{\mathrm{dw}}$ mice}

If the level and subcellular localization of prestin expression is sufficient for normal OHC motor function, then the nonlinear capacitance generated by mature mutant $\mathrm{OHCs}$ should be similar to that of hearing mice. Membrane capacitance was estimated from current transients elicited by a stair-step voltage protocol. These data were fit to Eq. 1 to determine the voltage-independent (linear, $C_{\text {lin }}$ ) and voltage-dependent (nonlinear, $C_{\text {nonlin }}$ ) components. Average capacitance curves are shown in Figure $4 B$ for wild-type OHCs at 2 and 2.5 weeks of age (P13-14 and P18-19, respectively) and for Pit ${ }^{\mathrm{dw}} \mathrm{OHCs}$ at 2,4 , and 6 weeks of age (P16-17, P30-32, and P43, respectively). Peak total membrane capacitance increased with age for both wild-type and mutant mice. Measures of voltage dependence ( $V_{1 / 2}$ and $\alpha$ in Eq. 1 ) were relatively unchanged over the age-ranges studied and across genotype (data not shown; $p>0.01$ ).

For wild-type mice, the increase in membrane capacitance reflected continued improvement in the nonlinear component from 2 to 2.5 weeks of age. Linear capacitance was constant over this age range (Fig. 4C), suggesting that the cells had reached a mature size even while the efficacy of prestin function or density of prestin molecules continued to increase. A previous report has suggested that nonlinear capacitance reaches a plateau $\sim 2$ weeks of age in normal mice (Abe et al., 2007). This subtle difference could represent differences in mouse strain background or husbandry.

For mutant mice, the developmental increase in total membrane capacitance reflected gains in both linear and nonlinear components (Fig. 4C). The gradual growth in linear capacitance from 2 to 6 weeks of age suggested a delay in the maturation of cell size in these animals compared with wild type. To address this possibility, OHCs were mechanically isolated from apical cochlear turns of P15-17 mice, and cell size was measured from captured digital images. Cell length and width for wild-type OHCs were $27.9 \pm 0.8$ and $6.8 \pm 0.3 \mu \mathrm{m}(N=13)$, respectively, whereas these measurements in Pit $1^{\mathrm{dw}}$ OHCs were $21.3 \pm 1.7$ and
$7.5 \pm 0.5 \mu \mathrm{m}(\mathrm{N}=5)$, respectively. The $24 \%$ difference in cell length is statistically significant $(p<0.01)$. Mean cell surface area was estimated from average length and width measurements, considering the $\mathrm{OHC}$ as a simple cylinder. The mean surface area of the wild-type OHCs was 1272 $\mu \mathrm{m}^{2}$, whereas that for Pit ${ }^{\mathrm{dw}}$ OHCs was $1085 \mu^{2}$, a reduction of $\sim 15 \%$. This size difference is similar to the difference in linear capacitance between mutant and wildtype cells at a similar age (18\%) (Fig. 4C). Nonlinear capacitance also increased with age in the mutant OHCs. The developmental change in nonlinear capacitance outpaced increases in linear capacitance, suggesting that increases in the nonlinear component must be attributed, at least in part, to a greater density and/or efficacy of prestin in the OHC membrane. These physiological tests reveal delayed maturation of prestin function in adult Pit $1^{\mathrm{dw}}$ mutants, consistent with the evidence that adult mutants eventually develop appropriate levels and subcellular localization of prestin protein. Thus, the lack of DPOAEs and CM in Pit ${ }^{\mathrm{dw}}$ mice is not explained by alterations in either nonlinear capacitance or prestin expression and localization. It remains possible, however, that electromotility is compromised in $P i t{ }^{\mathrm{dw}}$ mice through alterations in cytoskeletal structures essential to motor function or in the intrinsic electrical properties of the cell.

\section{Reduced KCNQ4 protein expression specifically in OHC of Pit1 ${ }^{\text {dw }}$ mutants}

The voltage-dependent $\mathrm{K}^{+}$channel KCNQ4 is responsible for the dominant $\mathrm{K}^{+}$conductance, $I_{K, n}$, of mature OHCs (Marcotti and Kros, 1999). KCNQ4 sets the membrane resting potential in cochlear hair cells, and loss of KCNQ4 may cause chronic stress for the cells and lead to their degeneration (Kharkovets et al., 2006). We examined expression of KCNQ4 in the cochlear and vestibular systems using immunohistochemical staining. In normal mice the KCNQ4 immunoreactivity is distributed across the entire $\mathrm{OHC}$ membrane during the first few days after birth, eventually shifting from the basolateral surface to the basal pole of the cell by P12-P13 (data not shown). The level of KCNQ4 immunoreactivity in Pit $^{\mathrm{dw}}$ mutants was reduced relative to wild type from P12 through P42 (Fig. 5A). The low level of KCNQ4 immunoreactivity appeared in a normal subcellular pattern. This differs from some rodent models of hypothyroidism that completely lack detectable KCNQ4 expression in OHCs at P12-P13 (Winter et al., 2006). We observed a developmental delay in KCNQ4 expression that followed a basal-apical gradient with expression levels in apical OHCs lagging behind those from the base (data not shown). In striking contrast to the OHC, the level of KCNQ4 expression within the spiral ganglion and vestibular organs of Pit $1{ }^{\mathrm{dw}}$ mutant inner ears was indistinguishable from that of wildtype mice at all ages tested (P13, P21, P42 and P60) (supplemental Figure S. $3 A$, available at www.jneurosci.org as supplemental material). This suggests that the permanent reduction in KCNQ4 expression is specific to the OHC in Pit ${ }^{\mathrm{dw}}$ mutants.

\section{Reduced KCNQ4 currents in Pit ${ }^{\mathrm{dw}}$ mutants}

To assess the functional consequences of the permanent reduction of KCNQ4 expression in mutants relative to normal $\mathrm{OHC}$, 
we measured KCNQ4 currents during development. Voltage activation curves were constructed from tail current analysis and fit with Boltzman functions (Eq. 2). Whole-cell currents in wild-type OHCs were dominated by a low-voltage activated conductance attributed to KCNQ4 channels (Marcotti and Kros, 1999). In the presence of linopirdine, a KCNQ4 blocker, total outward current was reduced due to the elimination of $I_{K, n}$, revealing a residual high-voltage activated potassium current (supplemental Figure S. 2, available at www.jneurosci.org as supplemental material). The shapes of activation curves from Pit $1^{\mathrm{dw}}$ mutant mice were heterogeneous suggesting large variations in the amount of KCNQ4-related conductance. While all cells from 2-week-old wild-type mice exhibited a dominant low-voltage activated KCNQ4 current, mutant OHCs, regardless of age, possessed varying mixtures of low- and high-voltage activated conductances (Fig. 5B). Occasionally, Pit $1^{\mathrm{dw}}$ mutant OHCs were best fit by a single Boltzman with a high $V_{1 / 2}$ (above $-20 \mathrm{mV}$ ), indicating the complete absence of measurable KCNQ4 current in those cells ( 4 of 17 cells in P15-17, 0 of 10 in P28-32, 1 of 18 in $\mathrm{P} 40-45)$. To compare the amount of KCNQ4 between experimental groups, we determined the maximum tail current from Boltzman fits to the low-voltage activated components in Figure $5 B$. This is an approximate measure of KCNQ4 current density since the sizes of all cells in this study were comparable (Fig. 4C). The data are plotted for each cell and as averages in Figure 5C. Maximum KCNQ4 current was reduced in all mutant age groups compared with wild type $(p<0.05)$. In contrast to results for nonlinear capacitance, the KCNQ4 current in mutants did not steadily increase toward mature wild-type levels. Instead, KCNQ4 current in the mutant animals peaked at 4 weeks of age (P28-35). Since KCNQ4 channels are active at negative membrane potentials, loss of KCNQ4 conductance would result in depolarization of the resting membrane potential. Currentclamp was used to measure resting potential in several OHCs from wild-type and mutant mice. The OHCs from mutant mice at 6 weeks of age were depolarized by 10 to $15 \mathrm{mV}$ compared with $\mathrm{OHCs}$ from 2-week-old wild-type mice (data not shown).

Substantially reduced endocochlear potential in Pit ${ }^{\mathrm{dw}}$ mice The EP is the main driving force for the sensory transduction that leads to perception of sound. The potential is generated across the basal cell barrier of the stria vascularis by the $\mathrm{K}^{+}$channel KCNJ10, which is located in the intermediate cells (Marcus et al., 2002; Rozengurt et al., 2003; Wangemann et al., 2004). We found that the EP in 6-week-old wild-type mice ranged from 105 to 113 $\mathrm{mV}(N=2)$, while the EP in Pit ${ }^{\mathrm{dw}}$ mutant mice was reduced by $45 \%$, ranging from 48 to $50 \mathrm{mV}(N=3)$ (Fig. 6A). Similarly, the EP of 3 -week-old mutants is $50 \%$ of wild type (data not shown). The abnormal EP contributes to the lack of DPOAE and CM and 2.5-week-old wild-type $\mathrm{OHCs}$.
B

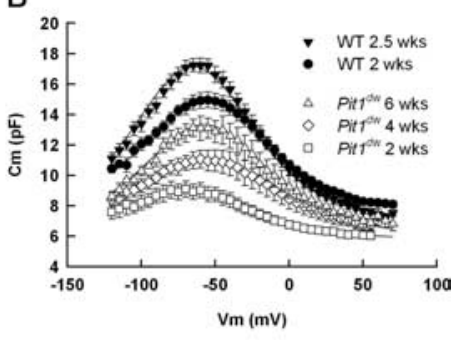

C

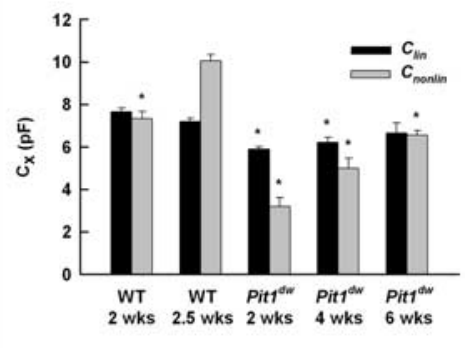

Figure 4. Prestin protein expression and function mature in adult Pit $1^{\mathrm{dw}}$ mutant mice. $A$, Prestin expression and localization was analyzed by staining paraffin-embedded sections from wild-type and Pit ${ }^{\text {dw }}$ mutants at P8, P14, P21, and P42 with prestinsecific antibodies (red). Sections were visualized with light microscopy. Synaptophysin (Syn) staining (green) identifies the basal pole Eq. 1 to estimate linear and nonlinear capacitance components. Fit parameters: WT: 2 weeks, $C_{\text {lin }}=7.7 \mathrm{pF}, \mathrm{Q}_{\max }=0.82 \mathrm{pC}, \alpha=$ $28.2 \mathrm{mV}, V_{1 / 2}=-56.3 \mathrm{mV} ; 2.5$ weeks, $C_{\text {lin }}=7.2 \mathrm{pF}, Q_{\max }=1.07 \mathrm{pC}, \alpha=26.9 \mathrm{mV}, \mathrm{V}_{1 / 2}=-65.0 \mathrm{mV} ;$ Pit $^{\mathrm{dw}}: 2$ weeks, $C_{\text {lin }}=$ . $\mathrm{mV} ; 6$ weeks, $C_{\text {lin }}=6.7 \mathrm{pF}, Q_{\max }=0.69 \mathrm{pC}, \alpha=26.8 \mathrm{mV}, V_{1 / 2}=-56.8 \mathrm{mV}$. C, Average values for linear and maximum nonlinear capacitance are shown for each experimental group. Error bars represent one SEM. ${ }^{*} p<0.01$ with respect to data from

indicates that a cochlear defect of peripheral origin is involved in the deafness characteristic of the Pit ${ }^{\mathrm{dw}}$ mutants.

\section{Reduced KCNJ10 protein expression in Pit $1^{\mathrm{dw}}$ mutants is} specific to the stria vascularis

The stria vascularis contains marginal cells, intermediate cells and basal cells. Defects in any of these cells can result in hearing deficits (Marcus et al., 2002; Jabba et al., 2006; Knipper et al., 2006; Jin et al., 2008). To investigate the cause of the reduced EP in Pit $1^{\mathrm{dw}}$ mutant mice, we examined the expression of the $\mathrm{K}^{+}$ channels KCNQ1 and KCNJ10 in marginal and intermediate cells, respectively, using immunohistochemical staining. The Pit $1^{\mathrm{dw}}$ mutant mice have reduced KCNJ10 immunoreactivity in both apical and basal cochlear turns compared with wild-type mice at P21 (data not shown) and P42 (Fig. 6B). The stria of the mutants appears smaller in width relative to wild type at both ages, and the smaller size seemed attributable to diminished contribution of intermediate cells. KCNJ10 expression is normal in Pit $1{ }^{\mathrm{dw}}$ mutant spiral ganglion and vestibular system at $\mathrm{P} 21$ and $\mathrm{P} 42$, revealing that the KCNJ10 deficiency is specific to the stria (supplemental Figure S. 3B, available at www.jneurosci.org as supplemental material). KCNQ1 is important for marginal cell 
A
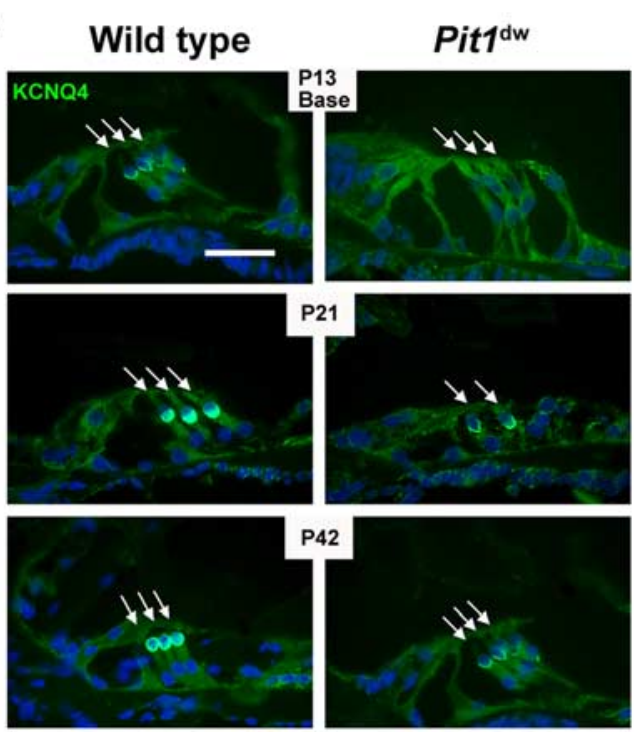

C

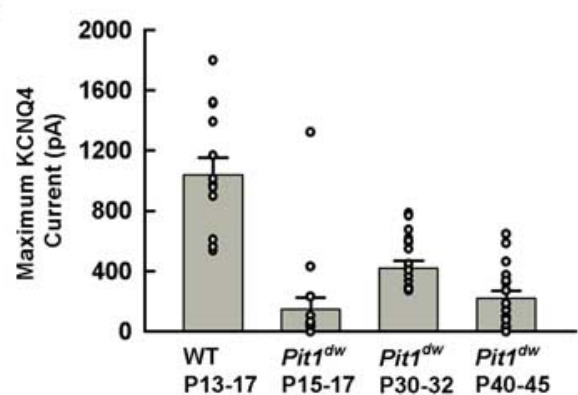

B
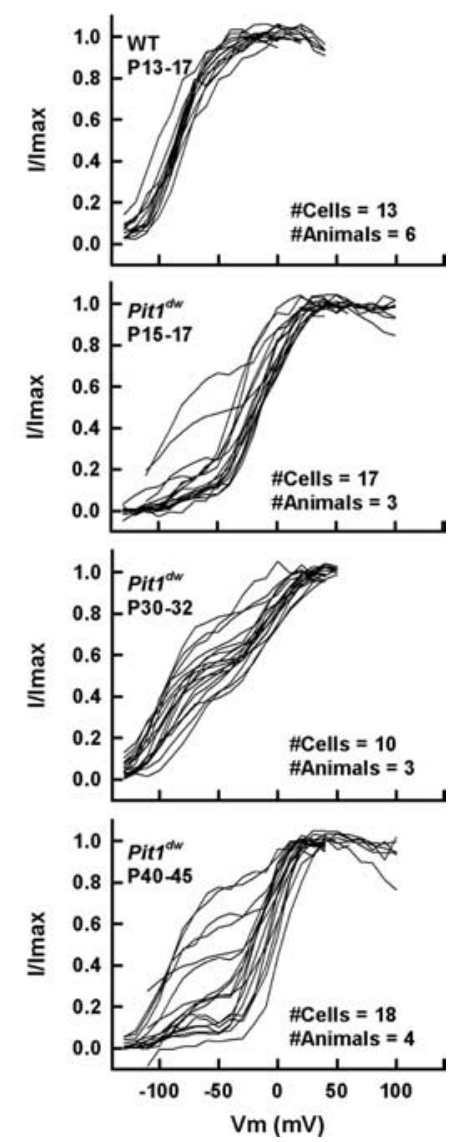

Figure 5. KCNQ4 protein expression and function are permanently reduced in the cochlear $\mathrm{OHC}$ of Pit ${ }^{\mathrm{dw}}$ mutant mice. $\boldsymbol{A}$, KCNQ4 immunoreactivity is reduced in $\mathrm{OHCS}$ (arrows) of mutant mice relative to wild type. Frozen sections obtained from P13, P21, and P42 wild-type and mutant mice were stained for KCNQ4 (green). Nuclei were stained with DAPI (blue). Outer hair cells from Pit ${ }^{\mathrm{dw}}$ mice exhibit a nonmonotonic developmental increase in KCNQ4 currents. B, Normalized tail-currents are shown for 2-week wild-type mice and 2-, 4-, and 6-week-old mutants. Wild-type OHCs uniformly exhibited a dominant low-voltage activated potassium conductance attributed to KCNQ4 function. Mutant OHCs were heterogeneous, regardless of age, in that some cells had KCNQ4 while others did not. C, Average maximum tail-current for low-voltage activated components of the Boltzman fits is shown for wild-type and mutant $\mathrm{OHCs}$. Average currents were lower in mutants than wild type $(p<0.05)$. Also, there was a statistically reliable effect of age on average KCNQ4 current using a one-way ANOVA $(p<0.01)$.

function and maintenance of stria (Rivas and Francis, 2005). No obvious differences in KCNQ1 expression are noted at P21 or P42 (data not shown). Thus, reduced KCNJ10 expression is likely to be a major contributor to the lowered EP observed in Pit1 ${ }^{\mathrm{dw}}$ mutants, as observed in the KCNJ10 knock-out (Marcus et al., 2002; Rozengurt et al., 2003; Wangemann et al., 2004).

\section{Stria vascularis pathology in adult Pit $1^{\mathrm{dw}}$ mutants}

We examined the stria vascularis at various ages in wild-type and mutant mice using light microscopy of hematoxylin and eosin stained paraffin sections (data not shown) and TEM (Fig. 7). Ultrastructure analysis reveals abnormalities in the stria that are more obvious in mutants at $\mathrm{P} 42(N=3$ per genotype and age) (Fig. 7A), than at P12 or P21 (data not shown). The width of the stria is consistently smaller in the mutant than the wild type. Marginal, intermediate, and basal cells all appear to be present, but there is less interdigitation of the intermediate cells with the basal aspect of the marginal cells and less infolding of the basolateral membrane. The smaller size of the mutant stria appears to come from reduced contribution of intermediate cells, consistent with reduced KCNJ10 immunostaining (Fig. 6). In addition, the
TEM analysis reveals prominent accumulation of dark deposits in the stria vascularis of P42 old Pit ${ }^{\mathrm{dw}}$ mutants with little or no deposits in wild-type littermates (Fig. 7B). The lipofuscin-like deposits (aging pigment) are found in all cell types of the stria, but are clearly most abundant in the central region of the stria, consistent with intermediate cells. The presence of this pathology suggests that cells in the stria vascularis of $P$ it $1^{\mathrm{dw}}$ mutants are undergoing deterioration.

\section{Discussion}

Congenital hypothyroidism impairs multiple developmental processes within the inner ear, offering a mechanistic explanation for hypothyroidism-induced deafness. We used Pit ${ }^{\mathrm{dw} / \mathrm{dw}}$ as a model of secondary hypothyroidism. These mice have profound congenital deafness but normal balance. We found no evidence of Pit1 expression in the cochlea using multiple approaches indicating that the hearing impairment in Pit1 mutants is caused by the lack of Pit1 activity in the pituitary gland (data not shown).

Pit $1^{\mathrm{dw} / \mathrm{dw}}$ have abnormalities in TM composition and ultrastructure, endolymph ionic balance, OHC survival, and strial cell health. These features contribute to the lack of DPOAE, CM, and the reduced EP, which can be attributed to longterm defects in OHC KCNQ4 expression and strial KCNJ10 expression. The mutant OHCs eventually exhibit normal prestin function and expression, but the defects in KCNQ4 are permanent. The strial intermediate cells exhibit persistently low $\mathrm{KCNJ} 10$ expression, resulting in ionic balance defects that likely contribute to the reduced $\mathrm{EP}, \mathrm{OHC}$ dysfunction, and sporadic $\mathrm{OHC}$ death. The profound hearing impairment characteristic of Pit ${ }^{\mathrm{dw} / \mathrm{dw}}$ may result from compounding effects of several hormone-dependent processes.

\section{Pit $1^{\mathrm{dw} / \mathrm{dw}}$ have tectorial membrane defects}

Pit $1^{\mathrm{dw} / \mathrm{dw}}$ TM abnormalities include increased size of Hensen's stripe and elevation of TECTB composition. Tect $b^{-/-}$lack Hensen's stripe, suggesting that TECTB is required to develop this structure (Russell et al., 2007). Thus, the increased TECTB in Pit $1^{\mathrm{dw} / \mathrm{dw}}$ could contribute to their prominent Hensen's stripe. While TSH-deficient $C g a^{\mathrm{tm} 1 / 1 \mathrm{tm} 1}$ also have a prominent Hensen's stripe (Karolyi et al., 2007), TECTB is decreased in pharmacologically induced hypothyroidism (Knipper et al., 2001). TM composition and the prominence of Hensen's stripe have not been assessed quantitatively in other models with impaired TH action, but ultrastructural abnormalities of the TM are common (Rusch et al., 2001; Richardson et al., 2008). The significance of altered $\mathrm{TM}$ composition and ultrastructure for $\mathrm{OHC}$ function is not clear (Knipper et al., 2001; Rusch et al., 2001; Richardson et al., 2008; Song et al., 2008). Mutations in individual TM components, Tecta, Tectb, and Otog, do not cause profound, congenital 
A
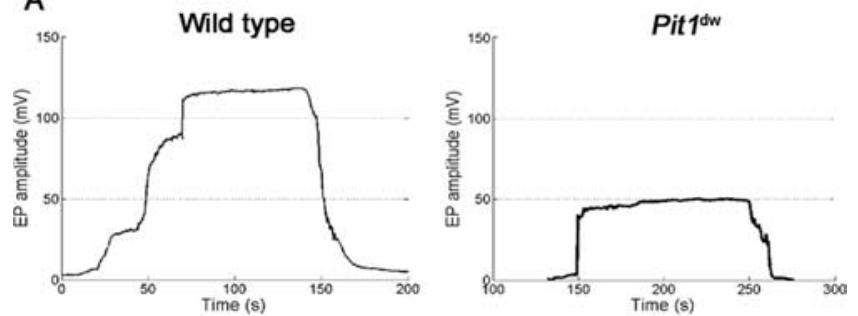

B
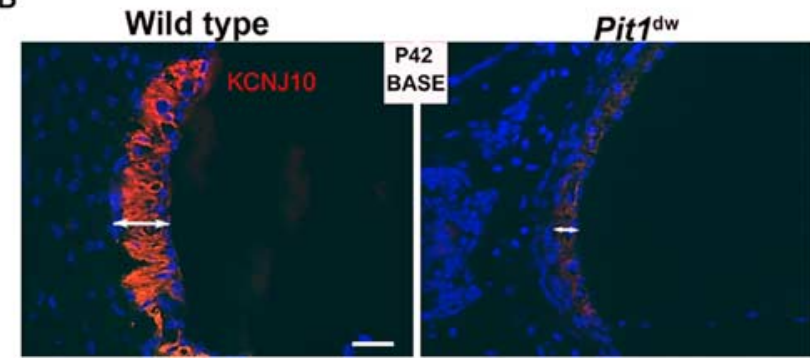

Figure 6. Endocochlear potential and KCNJ10 expression are lower in Pit $1^{\mathrm{dw}}$ mutants than wild type. $A$, EP were measured in P42 wild-type and age-matched mutant animals. Representative plots of endocochlear potential (in $\mathrm{mV}$ ) for littermate control and Pit $1^{\mathrm{dw}}$ mutant animals are shown. The time depicted includes electrode insertion into and withdrawal from the endolymph. $\boldsymbol{B}$, Frozen sections of the organ of Corti of wild-type and mutant mice collected at P21 and P42 were stained for KCNJ10 (red) (data shown for P42 only). Nuclei (blue). KCNJ10 immunoreactivity is detected in the intermediate cells of the stria vascularis of these mice.

deafness characteristic of Pit ${ }^{\mathrm{dw} / \mathrm{dw}}$, although multiple TM defects could have a compounding effect (Legan et al., 2000, 2005; Simmler et al., 2000; Russell et al., 2007).

\section{TH is not required for prestin expression or function}

Prestin is a motor protein that underlies OHC motility. TH regulates its transcription, and hypothyroidism causes abnormalities in prestin expression and subcellular distribution (Rusch et al., 2001; Weber et al., 2002; Winter et al., 2006). These abnormalities are transient in Pit $1^{\mathrm{dw} / \mathrm{dw}}$, representing delayed development that eventually matures. While data on prestin distribution and function in older drug treated and TR mutant animals are unavailable, we predict that prestin activity will mature functionally in pharmacologically treated animals as it does in Pit ${ }^{\mathrm{dw} / \mathrm{dw}}$. $\mathrm{OHC}$ motility may be compromised by observed defects in cytoskeletal specializations that support motor movement, but it seems unlikely that deficits in OHC motor function account completely for the absence of Pit ${ }^{\mathrm{dw} / \mathrm{dw}}$ DPOAEs and CM.

Maintenance of healthy cochlear cells is hormone dependent KCNQ4 expression and current is detectable in Pit ${ }^{\mathrm{dw} / \mathrm{dw}} \mathrm{OHCs}$ throughout adulthood, and the developmental profile of KCNQ4 currents is qualitatively similar to normal mice (Beisel et al., 2005). The persistently reduced KCNQ4 expression and function in $P$ Pit $1^{\mathrm{dw} / \mathrm{dw}}$ contrasts with the eventual maturation of prestin expression and function. Abnormal KCNQ4 expression results in chronic depolarization of Pit ${ }^{\mathrm{dw} / \mathrm{dw}}$ OHCs, which may lead to the untimely demise of OHCs that we observed in 6-week-old $P i t 1^{\mathrm{dw} / \mathrm{dw}}$. The level of depolarization we observed in $P i t 1^{\mathrm{dw} / \mathrm{dw}}$ OHCs was similar to that of Kcnq4 ${ }^{-1-}$ (Kharkovets et al., 2006). Mice with altered KCNQ4 conductance, through pharmacological block or genetic disruption, exhibit progressive OHC loss (Nouvian et al., 2003). This supports the idea that sporadic OHC loss occurs concomitant with reduced KCNQ4 conductance and a depolarized resting potential. We considered whether reduced Igf1 levels might cause OHC loss because complete lack of IGF1 causes $\mathrm{OHC}$ loss and severe hearing impairment (Camarero et al., 2001; Cediel et al., 2006). We concluded that the OHC loss in deaf $P$ it $1^{\mathrm{dw} / \mathrm{dw}}$ is not likely to be attributable to the reduced IGF1 levels because both Pit ${ }^{\mathrm{dw} / \mathrm{dw}}$ and normal-hearing Igf1 ${ }^{+/-}$animals have a $\sim 50 \%$ reduction in circulating IGF1 (Woods and Savage, 1996; Le Roith et al., 2001).

The OHC loss in Pit1 ${ }^{\mathrm{dw} / \mathrm{dw}}$ is unlikely to account for their profound congenital deafness because the timing is late and the fraction of hair cell death is small (Bohne et al., 1990). Stria vascularis dysfunction is likely to be an important contributor to the deafness. Normal EP is required for $\mathrm{OHC}$ function, including the generation of DPOAE and CM. Pit $1^{\mathrm{dw} / \mathrm{dw}}$ have approximately half the normal EP. Persistent reduction in KCNJ10 expression in the stria vascularis contributes to their low EP. This conclusion is supported by the observations that $\mathrm{Kcnj}_{10} \mathrm{O}^{-/-}$mice lack EP and have compromised hearing (Marcus et al., 2002) and Slc26a4 ${ }^{-/-}$, a euthyroid model of Pendred syndrome, lack both EP and KCNJ10 (Rusch et al., 2001; Wangemann et al., 2004). We predict that KCNJ10 expression is reduced in the stria vascularis of hypothyroid and TR mutant animals. This would be expected to reduce, but not eliminate, DPOAE and ABR responses (Gow et al., 2004). Thus, the absence of DPOAE in Pit $1^{\mathrm{dw} / \mathrm{dw}}$ arises from a combination of several deficits.

Pit $1^{\mathrm{dw} / \mathrm{dw}}$ stria are small with abnormalities in ultrastructure including accumulation of lipofuscin-like deposits. The decreased stria size in Pit $1^{\mathrm{dw} / \mathrm{dw}}$ appears independent of KCNJ10 because complete absence of KCNJ10 in Slc26a4 and Kcnj10 mutants does not cause this morphological effect (Marcus et al., 2002; Wangemann et al., 2004). Lipofuscin accumulation accelerates in aging cochleae (Nadol, 1979; Kazee and West, 1999), brains of Alzheimer's and Parkinson's patients (Eichhoff et al., 2008), and eyes of patients with atrophic age-related macular degeneration (Holz et al., 1999; Schmitz-Valckenberg et al., 2004). Thus, the stria vascularis pathology suggests that Pit $1^{\mathrm{dw} / \mathrm{dw}}$ cells are undergoing changes associated with physiological stress or premature aging. This is surprising because Pit $1^{\mathrm{dw} / \mathrm{dw}}$ and animals with GH defects have reduced cellular stress and enhanced longevity (Leiser et al., 2006). The etiology of the stria pathology in $P i t 1^{\mathrm{dw} / \mathrm{dw}}$ is not known, but stria development and maintenance are hormone-dependent.

Many genetic defects disrupt development and function of both the vestibular apparatus and the cochlea, yet hypothyroidism only affects the cochlea. The basis for this specificity is unknown. Intriguingly, the alteration in KCNQ4 and KCNJ10 expression in Pit $1^{\mathrm{dw} / \mathrm{dw}}$ is confined to OHCs and stria, respectively. This cell type specific dysregulation suggests that the same genes have different requirements for hormonal regulation in various cell types within the same organ. This could be achieved by many mechanisms, such as utilization of different cell-type specific transcription components and/or deiodinases. Alternatively, variation in the critical timing for hormone exposure could underlie differences in hormone sensitivity, where cells differentiating early benefit from maternal hormones during gestation, while cell types differentiating later depend on neonatal hormone production.

\section{Why are $P i t 1^{\mathrm{dw} / \mathrm{dw}}$ profoundly deaf?}

Thyroid hormone regulates many processes in the developing cochlea. Individual defects in TM, DPOAE, CM, EP, prestin, Kcnq4, and Kcnj10 are consistent with progressive and/or moderate to severe hearing impairment. The profound hearing im- 


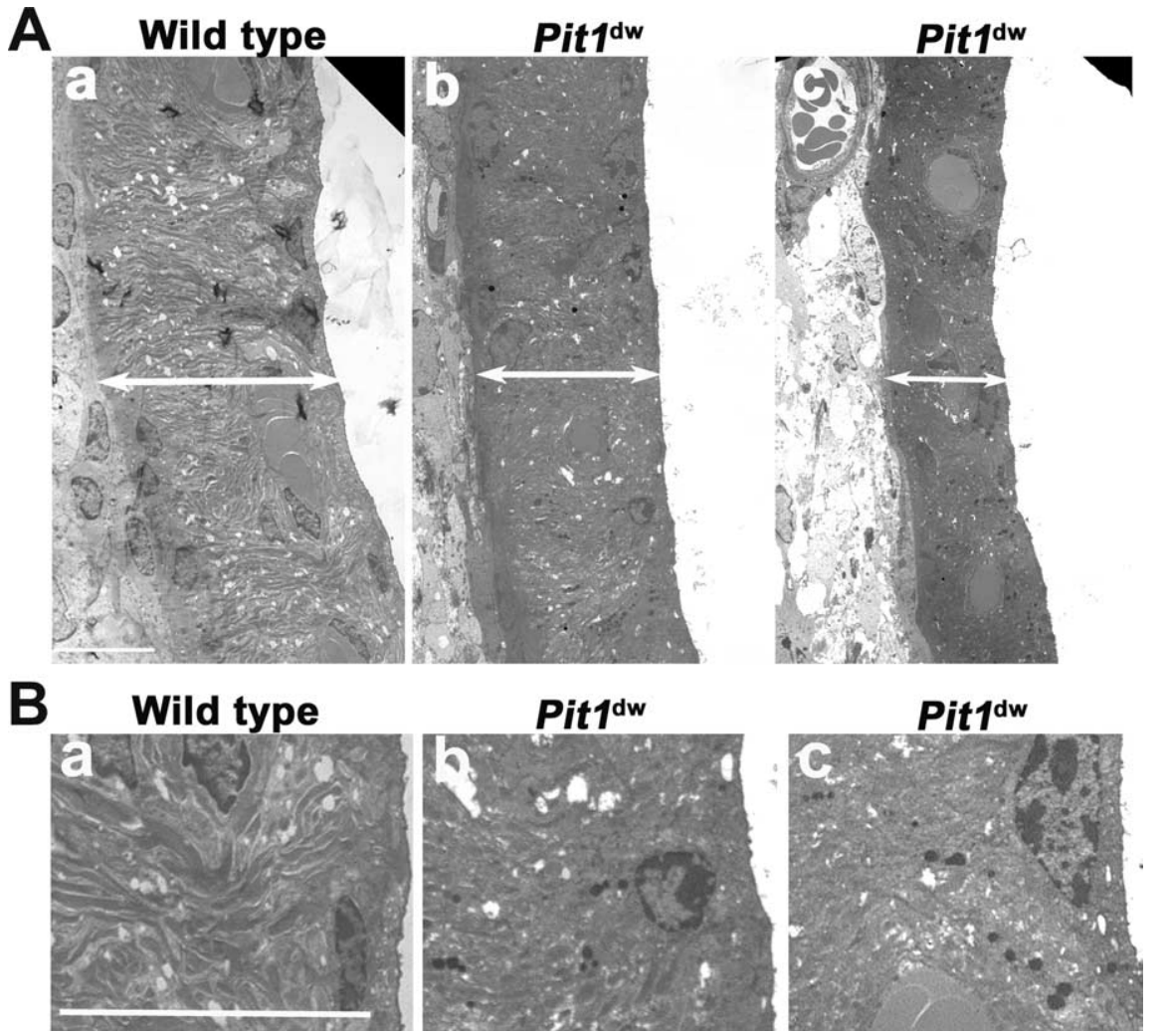

Figure 7. Stria vascularis pathology in adult Pit1 mutants. $\boldsymbol{A}$, Stria vascularis prepared from $\mathrm{P} 42$ wild-type mice $(\boldsymbol{a})$ and mutant mice $(\boldsymbol{b}, \boldsymbol{c})$ were analyzed by TEM. Double-headed arrow bars define the width of the stria vascularis. $\boldsymbol{B}$, Lipofuscin granules are more abundant in the intermediate cells of Pit ${ }^{\mathrm{d} w}$ mutant mice, suggesting that the mutant cells are exhibiting signs of aging. The ultrastructure of wild-type $(\boldsymbol{a})$ stria vascularis animals was compared with Pit ${ }^{\mathrm{dw}}$ mutants $(\boldsymbol{b}, \boldsymbol{c})$. Lipofuscin-like granules are more abundant in the mutants. Sections shown are from the basal turns of the cochlea, which were more prominently affected than the apex. Scale bars: $10 \mu \mathrm{m}$.

pairment observed in Pit ${ }^{\mathrm{dw} / \mathrm{dw}}$ could be explained by a compounding effect of genes that individually have moderate effects or there could be additional processes involved. Given the broad effects of TH on gene expression, other processes, such as IHC function, neurotransmission, and innervation, are likely compromised (Brandt et al., 2007; Sendin et al., 2007).

\section{Advantages of the Pit $1^{\mathrm{dw} / \mathrm{dw}}$ model}

The advantages of studying $P i t 1^{\mathrm{dw} / \mathrm{dw}}$ are their viability and responsiveness to $\mathrm{TH}$ supplementation, which makes it possible to distinguish the aspects of $\mathrm{TH}$ deficiency that lead to permanent hearing defects from those that cause developmental delay. For example, the developmental delay in prestin expression is not permanent, but the alterations in the TM and defective KCNJ10 and KCNQ4 expression and function are. In addition, Pit $1^{\mathrm{dw} / \mathrm{dw}}$ reveal the importance of $\mathrm{TH}$ for stria vascularis and $\mathrm{OHC}$ function and for avoiding pathological changes and cell death. The prominence of hypothyroidism and presbycusis in older individuals suggests that our studies may be important for understanding the mechanisms contributing to age related hearing loss (ARHL).

\section{Is hypothyroidism a risk factor presbycusis?}

There are several lines of evidence that suggest hormone deficiency may be a risk factor for presbycusis. OHC loss and strial abnormalities of the Pit $1^{\mathrm{dw} / \mathrm{dw}}$ cochleae are also found in cases of age-related and environmentally induced hearing loss. In addition, the Pit ${ }^{\mathrm{dw} / \mathrm{dw}}$ exhibit reduced Kcnq4 expression, a gene mu- tated in autosomal dominant hearing loss is also associated with presbycusis (Van Eyken et al., 2006).

Hypothyroidism is common in older individuals (Fransen et al., 2003) and GH production decreases with age (Lanfranco et al., 2003; Bartke, 2005). Since hormones are necessary for cochlear cell survival and function in young mice, it is possible that reduced hormone production in adults is a risk factor for ARHL, or that individuals born from mothers with hypothyroidism during pregnancy could be predisposed to ARHL. While this is speculative, the mouse could be an excellent tool to investigate genetic and environmental modifiers of ARHL (Johnson and Zheng, 2002; Nemoto et al., 2004).

\section{References}

Abe S, Katagiri T, Saito-Hisaminato A, Usami S, Inoue Y, Tsunoda T, Nakamura Y (2003) Identification of CRYM as a candidate responsible for nonsyndromic deafness, through cDNA microarray analysis of human cochlear and vestibular tissues. Am J Hum Genet 72:73-82.

Abe T, Kakehata S, Kitani R, Maruya S, Navaratnam D, Santos-Sacchi J, Shinkawa H (2007) Developmental expression of the outer hair cell motor prestin in the mouse. J Membr Biol 215:49-56.

Bartke A (2005) Minireview: role of the growth hormone/insulin-like growth factor system in mammalian aging. Endocrinology 146: $3718-3723$.

Beisel KW, Rocha-Sanchez SM, Morris KA, Nie L, Feng F, Kachar B, Yamoah EN, Fritzsch B (2005) Differential expression of KCNQ4 in inner hair cells and sensory neurons is the basis of progressive high-frequency hearing loss. J Neurosci 25:9285-9293.

Beyer LA, Odeh H, Probst FJ, Lambert EH, Dolan DF, Camper SA, Kohrman DC, Raphael Y (2000) Hair cells in the inner ear of the pirouette and shaker 2 mutant mice. J Neurocytol 29:227-240.

Bohne BA, Gruner MM, Harding GW (1990) Morphological correlates of aging in the chinchilla cochlea. Hear Res 48:79-91.

Brandt N, Kuhn S, Münkner S, Braig C, Winter H, Blin N, Vonthein R, Knipper M, Engel J (2007) Thyroid hormone deficiency affects postnatal spiking activity and expression of $\mathrm{Ca}^{2+}$ and $\mathrm{K}^{+}$channels in rodent inner hair cells. J Neurosci 27:3174-3186.

Brown-Borg HM, Borg KE, Meliska CJ, Bartke A (1996) Dwarf mice and the ageing process. Nature 384:33.

Camarero G, Avendano C, Fernandez-Moreno C, Villar A, Contreras J, de Pablo F, Pichel JG, Varela-Nieto I (2001) Delayed inner ear maturation and neuronal loss in postnatal Igf-1-deficient mice. J Neurosci 21:7630-7641.

Camper SA, Saunders TL, Katz RW, Reeves RH (1990) The Pit-1 transcription factor gene is a candidate for the Snell dwarf mutation. Genomics 8:586-590.

Cantos R, López DE, Merchán JA, Rueda J (2003) Olivocochlear efferent innervation of the organ of corti in hypothyroid rats. J Comp Neurol 459:454-467.

Cediel R, Riquelme R, Contreras J, Díaz A, Varela-Nieto I (2006) Sensorineural hearing loss in insulin-like growth factor I-null mice: a new model of human deafness. Eur J Neurosci 23:587-590.

Cheatham MA, Huynh KH, Gao J, Zuo J, Dallos P (2004) Cochlear function in Prestin knockout mice. J Physiol 560:821-830.

Christ S, Biebel UW, Hoidis S, Friedrichsen S, Bauer K, Smolders JW (2004) Hearing loss in athyroid pax8 knockout mice and effects of thyroxine substitution. Audiol Neurootol 9:88-106. 
Dallos P, Wu X, Cheatham MA, Gao J, Zheng J, Anderson CT, Jia S, Wang X, Cheng WH, Sengupta S, He DZ, Zuo J (2008) Prestin-based outer hair cell motility is necessary for mammalian cochlear amplification. Neuron 58:333-339.

Deol MS (1973) Congenital deafness and hypothyroidism. Lancet 2:105-106.

Eichhoff G, Busche MA, Garaschuk O (2008) In vivo calcium imaging of the aging and diseased brain. Eur J Nucl Med Mol Imaging [Suppl 1]:S99-S106.

Fransen E, Lemkens N, Van Laer L, Van Camp G (2003) Age-related hearing impairment (ARHI): environmental risk factors and genetic prospects. Exp Gerontol 38:353-359.

Gage PJ, Brinkmeier ML, Scarlett LM, Knapp LT, Camper SA, Mahon KA (1996) The Ames dwarf gene, df, is required early in pituitary ontogeny for the extinction of $R p x$ transcription and initiation of lineage specific cell proliferation. Mol Endocrinol 10:1570-1581.

Gao J, Wang X, Wu X, Aguinaga S, Huynh K, Jia S, Matsuda K, Patel M, Zheng J, Cheatham M, He DZ, Dallos P, Zuo J (2007) Prestin-based outer hair cell electromotility in knockin mice does not appear to adjust the operating point of a cilia-based amplifier. Proc Natl Acad Sci U S A 104:12542-12547.

Godfrey P, Rahal JO, Beamer WG, Copeland NG, Jenkins NA, Mayo KE (1993) GHRH receptor of little mice contains a missense mutation in the extracellular domain that disrupts receptor function. Nat Genet 4:227-232.

Gow A, Davies C, Southwood CM, Frolenkov G, Chrustowski M, Ng L, Yamauchi D, Marcus DC, Kachar B (2004) Deafness in Claudin 11-null mice reveals the critical contribution of basal cell tight junctions to stria vascularis function. J Neurosci 24:7051-7062.

Holz FG, Schütt F, Kopitz J, Völcker HE (1999) [Introduction of the lipofuscin-fluorophor A2E into the lysosomal compartment of human retinal pigment epithelial cells by coupling to LDL particles. An in vitro model of retinal pigment epithelium cell aging]. Ophthalmologe 96:781-785.

Huang G, Santos-Sacchi J (1993) Mapping the distribution of the outer hair cell motility voltage sensor by electrical amputation. Biophys J 65:2228-2236.

Jabba SV, Oelke A, Singh R, Maganti RJ, Fleming S, Wall SM, Everett LA, Green ED, Wangemann P (2006) Macrophage invasion contributes to degeneration of stria vascularis in Pendred syndrome mouse model. BMC Med 4:37.

Jin Z, Ulfendahl M, Jarlebark L (2008) Spatiotemporal loss of K+ transport proteins in the developing cochlear lateral wall of guinea pigs with hereditary deafness. Eur J Neurosci 27:145-154.

Johnson KR, Zheng QY (2002) Ahl2, a second locus affecting age-related hearing loss in mice. Genomics 80:461-464.

Karolyi IJ, Dootz GA, Halsey K, Beyer L, Probst FJ, Johnson KR, Parlow AF, Raphael Y, Dolan DF, Camper SA (2007) Dietary thyroid hormone replacement ameliorates hearing deficits in hypothyroid mice. Mamm Genome 18:596-608.

Kazee AM, West NR (1999) Preservation of synapses on principal cells of the central nucleus of the inferior colliculus with aging in the CBA mouse. Hear Res 133:98-106.

Kharkovets T, Dedek K, Maier H, Schweizer M, Khimich D, Nouvian R, Vardanyan V, Leuwer R, Moser T, Jentsch TJ (2006) Mice with altered KCNQ4 K+ channels implicate sensory outer hair cells in human progressive deafness. EMBO J 25:642-652.

Knipper M, Bandtlow C, Gestwa L, Köpschall I, Rohbock K, Wiechers B, Zenner HP, Zimmermann U (1998) Thyroid hormone affects Schwann cell and oligodendrocyte gene expression at the glial transition zone of the VIIIth nerve prior to cochlea function. Development 125:3709-3718.

Knipper M, Zinn C, Maier H, Praetorius M, Rohbock K, Köpschall I, Zimmermann U (2000) Thyroid hormone deficiency before the onset of hearing causes irreversible damage to peripheral and central auditory systems. J Neurophysiol 83:3101-3112.

Knipper M, Richardson G, Mack A, Müller M, Goodyear R, Limberger A, Rohbock K, Köpschall I, Zenner HP, Zimmermann U (2001) Thyroid hormone-deficient period prior to the onset of hearing is associated with reduced levels of beta-tectorin protein in the tectorial membrane: implication for hearing loss. J Biol Chem 276:39046-39052.

Knipper M, Claussen C, Ruttiger L, Zimmermann U, Lullmann-Rauch R, Eskelinen EL, Schroder J, Schwake M, Saftig P (2006) Deafness in
LIMP2-deficient mice due to early loss of the potassium channel KCNQ1/ KCNE1 in marginal cells of the stria vascularis. J Physiol 576:73-86.

Lanfranco F, Gianotti L, Giordano R, Pellegrino M, Maccario M, Arvat E (2003) Ageing, growth hormone and physical performance. J Endocrinol Invest 26:861-872.

Legan PK, Lukashkina VA, Goodyear RJ, Kössi M, Russell IJ, Richardson GP (2000) A targeted deletion in alpha-tectorin reveals that the tectorial membrane is required for the gain and timing of cochlear feedback. Neuron 28:273-285.

Le Roith D, Scavo L, Butler A (2001) What is the role of circulating IGF-I?. Trends Endocrinol Metab 12:48-52.

Legan PK, Lukashkina VA, Goodyear RJ, Lukashkin AN, Verhoeven K, Van Camp G, Russell IJ, Richardson GP (2005) A deafness mutation isolates a second role for the tectorial membrane in hearing. Nat Neurosci 8:1035-1042.

Leiser SF, Salmon AB, Miller RA (2006) Correlated resistance to glucose deprivation and cytotoxic agents in fibroblast cell lines from long-lived pituitary dwarf mice. Mech Ageing Dev 127:821-829.

Li D, Henley CM, O’Malley BW Jr (1999) Distortion product otoacoustic emissions and outer hair cell defects in the hyt/hyt mutant mouse. Hear Res 138:65-72.

Li S, Crenshaw EB 3rd, Rawson EJ, Simmons DM, Swanson LW, Rosenfeld MG (1990) Dwarf locus mutants lacking three pituitary cell types result from mutations in the POU-domain gene pit-1. Nature 347:528-533.

Li S, Price SM, Cahill H, Ryugo DK, Shen MM, Xiang M (2002) Hearing loss caused by progressive degeneration of cochlear hair cells in mice deficient for the Barhl1 homeobox gene. Development 129:3523-3532.

Liberman MC, Gao J, He DZ, Wu X, Jia S, Zuo J (2002) Prestin is required for electromotility of the outer hair cell and for the cochlear amplifier. Nature 419:300-304.

Lin SC, Lin CR, Gukovsky I, Lusis AJ, Sawchenko PE, Rosenfeld MG (1993) Molecular basis of the little mouse phenotype and implications for cell type-specific growth. Nature 364:208-213.

Marcotti W, Kros CJ (1999) Developmental expression of the potassium current IK,n contributes to maturation of mouse outer hair cells. J Physiol 520:653-660.

Marcus DC, Wu T, Wangemann P, Kofuji P (2002) KCNJ10 (Kir4.1) potassium channel knockout abolishes endocochlear potential. Am J Physiol Cell Physiol 282:C403-C407.

Mustapha M, Beyer LA, Izumikawa M, Swiderski DL, Dolan DF, Raphael Y, Camper SA (2007) Whirler mutant hair cells have less severe pathology than shaker 2 or double mutants. J Assoc Res Otolaryngol 8:329-337.

Nadol JB Jr (1979) Electron microscopic findings in presbycusic degeneration of the basal turn of the human cochlea. Otolaryngol Head Neck Surg $87: 818-836$.

Nemoto M, Morita Y, Mishima Y, Takahashi S, Nomura T, Ushiki T, Shiroishi T, Kikkawa Y, Yonekawa H, Kominami R (2004) Ahl3, a third locus on mouse chromosome 17 affecting age-related hearing loss. Biochem Biophys Res Commun 324:1283-1288.

Nouvian R, Ruel J, Wang J, Guitton MJ, Pujol R, Puel JL (2003) Degeneration of sensory outer hair cells following pharmacological blockade of cochlear KCNQ channels in the adult guinea pig. Eur J Neurosci 17:2553-2562.

Oliver D, Fakler B (1999) Expression density and functional characteristics of the outer hair cell motor protein are regulated during postnatal development in rat. J Physiol 519:791-800.

Patuzzi RB, Yates GK, Johnstone BM (1989) Changes in cochlear microphonic and neural sensitivity produced by acoustic trauma. Hear Res 39:189-202.

Richardson GP, Lukashkin AN, Russell IJ (2008) The tectorial membrane: one slice of a complex cochlear sandwich. Curr Opin Otolaryngol Head Neck Surg 16:458-464.

Rivas A, Francis HW (2005) Inner ear abnormalities in a Kcnq1 (Kvlqt1) knockout mouse: a model of Jervell and Lange-Nielsen syndrome. Otol Neurotol 26:415-424.

Rozengurt N, Lopez I, Chiu CS, Kofuji P, Lester HA, Neusch C (2003) Time course of inner ear degeneration and deafness in mice lacking the Kir4.1 potassium channel subunit. Hear Res 177:71-80.

Rueda J, Prieto JJ, Cantos R, Sala ML, Merchán JA (2003) Hypothyroidism prevents developmental neuronal loss during auditory organ development. Neurosci Res 45:401-408.

Rusch A, Erway LC, Oliver D, Vennstrom B, Forrest D (1998) Thyroid hor- 
mone receptor beta-dependent expression of a potassium conductance in inner hair cells at the onset of hearing. Proc Natl Acad Sci U S A 95:15758-15762.

Rusch A, Ng L, Goodyear R, Oliver D, Lisoukov I, Vennstrom B, Richardson G, Kelley MW, Forrest D (2001) Retardation of cochlear maturation and impaired hair cell function caused by deletion of all known thyroid hormone receptors. J Neurosci 21:9792-9800.

Russell IJ, Legan PK, Lukashkina VA, Lukashkin AN, Goodyear RJ, Richardson GP (2007) Sharpened cochlear tuning in a mouse with a genetically modified tectorial membrane. Nat Neurosci 10:215-223.

Schmitz-Valckenberg S, Bültmann S, Dreyhaupt J, Bindewald A, Holz FG, Rohrschneider K (2004) Fundus autofluorescence and fundus perimetry in the junctional zone of geographic atrophy in patients with agerelated macular degeneration. Invest Ophthalmol Vis Sci 45:4470-4476.

Sendin G, Bulankina AV, Riedel D, Moser T (2007) Maturation of ribbon synapses in hair cells is driven by thyroid hormone. J Neurosci 27:3163-3173.

Simmler MC, Cohen-Salmon M, El-Amraoui A, Guillaud L, Benichou JC, Petit C, Panthier JJ (2000) Targeted disruption of otog results in deafness and severe imbalance. Nat Genet 24:139-143.

Song L, McGee J, Walsh EJ (2008) The influence of thyroid hormone deficiency on the development of cochlear nonlinearities. J Assoc Res Otolaryngol 9:464-476.

Uziel A (1986) Periods of sensitivity to thyroid hormone during the development of the organ of Corti. Acta Otolaryngol Suppl 429:23-27.

Uziel A, Legrand C, Ohresser M, Marot M (1983) Maturational and degenerative processes in the organ of Corti after neonatal hypothyroidism. Hear Res 11:203-218.
Vanderschueren-Lodeweyckx M, Debruyne F, Dooms L, Eggermont E, Eeckels R (1983) Sensorineural hearing loss in sporadic congenital hypothyroidism. Arch Dis Child 58:419-422.

Van Eyken E, Van Laer L, Fransen E, Topsakal V, Lemkens N, Laureys W, Nelissen N, Vandevelde A, Wienker T, Van De Heyning P, Van Camp G (2006) KCNQ4: a gene for age-related hearing impairment?. Hum Mutat 27:1007-1016.

Van't Hoff W, Stuart DW (1979) Deafness in myxoedema. Q J Med 48:361-367.

Wangemann P, Itza EM, Albrecht B, Wu T, Jabba SV, Maganti RJ, Lee JH, Everett LA, Wall SM, Royaux IE, Green ED, Marcus DC (2004) Loss of KCNJ10 protein expression abolishes endocochlear potential and causes deafness in Pendred syndrome mouse model. BMC Med 2:30.

Weber T, Zimmermann U, Winter H, Mack A, Köpschall I, Rohbock K, Zenner HP, Knipper M (2002) Thyroid hormone is a critical determinant for the regulation of the cochlear motor protein prestin. Proc Natl Acad Sci U S A 99:2901-2906.

Winter H, Braig C, Zimmermann U, Geisler HS, Fränzer JT, Weber T, Ley M, Engel J, Knirsch M, Bauer K, Christ S, Walsh EJ, McGee J, Köpschall I, Rohbock K, Knipper M (2006) Thyroid hormone receptors TRalphal and TRbeta differentially regulate gene expression of Kcnq4 and prestin during final differentiation of outer hair cells. J Cell Sci 119:2975-2984.

Woods KA, Savage MO (1996) Laron syndrome: typical and atypical forms. Baillieres Clin Endocrinol Metab 10:371-387.

Zheng J, Shen W, He DZ, Long KB, Madison LD, Dallos P (2000) Prestin is the motor protein of cochlear outer hair cells. Nature 405:149-155. 